\title{
Što je sve film? ${ }^{1}$
}

\section{prof. dr. sc. HRVOJE TURKOVIĆ}

Akademija dramskih umjetnosti, Sveučilište u Zagrebu

\section{SAŽETAK}

U radu se sažeto daju jezgrene teorijske odrednice filma, odnosno audiovizualnog djela i područja, one koje su relevantnim orijentirima pogodne za empirijska istraživanja. Prvo, filmsko djelo je ograničena tvarna pojava u ljudskom okružju, njome se može baratati i prema njoj nekako životno odnositi. Drugo, posrijedi je tehnološki temeljena izrađevina, koja je uvjetovana tehnologijom i uvjetuje popratni razvoj i razradu tehnike za svoje potrebe. Treće, film se izrađuje kako bi potakao i razrađivao reakcije u ljudi, i to mu je temeljna uporabna svrha. Četvrto, tehnološko vladanje izrađivanjem omogućuje kontrolirano izrađivačko modeliranje gledateljevih doživljaja, pa je film, utoliko, epistemološkomodelotvornom izrađevinom. Modeliranje podrazumijeva dva tipa komunikacijskog sudjelovanja: izrađivači adresiraju potencijalne ili stvarne gledatelje, ali i gledatelji međusobno (kao publika) dijele iskustva gledanja činjenicom da su izloženi filmskoj izrađevini, njezinim modelotvornim poticajima. Peto, sve je to prethodno ujedno i društveno-kulturni čin, film crpi iz okružujuće kulture i njezinim je čimbenikom. Šesto, film je u svim svojim aspektima društven i utoliko je neizbježno društveno organizacijski i institucijski podržan.

Ključne riječi: filmsko djelo, filmska tehnologija, epistemologija filma, ontologija filma, filmska kultura

1 Ovaj je rad prerada i razrada prethodnog nacrta (draft) dostupnog na akademskim internetskim stranicama academia.edu (www.academia.edu/8964145/Što_je_sve_film_Ontologija_filma_All_a_film_is_Film_Ontology_). Posrijedi je pokušaj da objedinim jezgrene spoznaje o filmu koje sam stjecao i razrađivao tijekom desetljeća filmološkog spisateljskog i predavačkog rada. 


\section{Film je tvarno vezana pojava, tj. filmsko djelo je materijalno ukotvljeno}

Po nekim obvezatnim značajkama filmsko djelo ${ }^{2}$ je tvarnosna pojava ograničenog prostornog smještaja u stvarnom ambijentu te ograničene događajne protežnosti, trajanja; stvarna pojava među različitim drugim u životnom okolišu. Filozofsko-ontološki: on je prostorno-vremenski određenom, ograničenom materijalnom pojavom, lokalno perceptibilnom pojavom.

Na primjer, filmska slika zauzima ograničeno područje u kinu ili prostoriji u kojoj se odvija: riječ je uglavnom o pravokutniku promjenjivo osvijetljenom, dinamične smjene zasjenjenja na nekom refleksijskom ili emisijskom ekranu (na filmskom platnu, ekranu nekog elektroničkog uređaja ili na nekoj površini u ambijentu gledanja); to pravokutno područje proizvedeno je snopom svjetla koji ima izvor u projektoru ili elektroničkom ekranu, odnosno u filmskoj vrpci ili elektroničkom zapisu s koje se projicira ili emitira. Sve je to nekako ograničeno smješteno u ambijentu, dade se time rukovati i traje određeno vrijeme kao i drugi prolazni događaji u našem životu.

Tijekom povijesti mijenjao se nosač filmskog djela. Mijenjao se od filma kao zapisa na filmskoj vrpci, preko analognog zapisa na elektromagnetskoj vrpci, a danas kao digitalnog memorijskog zapisa u nekom od nositelja digitalnih zapisa. Projekciji na filmsko platno pridružile su se emisije s nekog elektroničkog ekrana. No bez obzira na sve te promjene, film je i nadalje ostao nekako fizički ukotvljen, u nečemu zapisan i na nekom ekranu prikazan, i nadalje lokalnom tvarnom pojavom u našem životnom okolišu, s kojom se dade fizički baratati.

Iako rijetko teorijski razmatrana, ova je osobina ključnim temeljem mnogih drugih osobina filmskog djela i filmskog stvaralaštva. Ona temeljem izrađivačke prirode filma, temeljcem je gledateljskog životno-organizacijskog i doživljajnog odnosa prema filmu, temeljem je posredovalačkog, medijsko-komunikacijskog, pa i društveno organizacijskog funkcioniranja filma (kinematografije, audiovizualne industrije).

Zaključimo: status filma kao lokalne tvarne pojave naše okoline ključan je aspekt stvaranja filma, našeg doživljaja filma, te njegova statusa u ljudskoj civilizacijsko-materijalnoj i društvenoj svakodnevici.

\section{Film je izrađevina, tehnološki temeljena i razvijana}

Između različitih tvarno vezanih pojava, filmska pojava (filmsko djelo) spada u posebnu vrstu: $\mathrm{u}$ izrađevine (artefakte, proizvode, djela) koje su ciljni rezultat intencionalnog ljudskog izrađivanja.

Izrađivanje podrazumijeva vođenu preobliku nekih tvarno vezanih pojava iz njihova polazna stanja (stanja sirovine, građe, materijala...) do nekog traženog konačnog stanja (konačnog proizvoda, djela...), pomoću nekih sredstava (oruđa, instrumenata /tehnike/...) i usmjerenih znanja i postupaka (iskustva, vještina, rutina), te posebnog proizvodnog, prevladavajuće tehničkog instrumentarija i proizvodnih procesa i specijaliziranih radnih konteksta.

2 Pod „filmskim djelom“ ovdje se podrazumijeva ono što se suvremeno kolokvijalno još povremeno naziva „pokretnim slikama“ ili službeno „audiovizualnim djelom“, što su sve pojmovi koji se rabe generički, tj. teže obuhvatiti različite povijesne medijske varijante tradicionalnog „filma“. Razlog je konzervativan, ali s opravdanjem. Prvo, kolokvijalno se (a i u stručnim djelima) još uvijek udomaćeno govori o „filmu“ ne samo onda kada je riječ o djelu napravljenom na filmskoj vrpci i prikazivanom s nje, nego i onda kada je riječ o filmu izvorno rađenom na filmskoj vrpci, ali prebačenom na elektronički nosač i prikazivanom s njega, kao i onda kada je posrijedi videodjelo, tj. djelo nastalo i prikazivano elektronički (analogno i digitalno). Teorijski važniji razlog je, što se i novije elektroničke varijante „audiovizualnih djela“ mogu shvatiti samo kao svojevrsne razrade i inačice još uvijek identifikacijski obilježene jezgrenim karakteristikama tradicionalnog filma (Manovich, 2001), pa se i konzervativna uporaba termina „film“, „filmsko djelo“ za novije elektroničke varijante (ne samo videodjela, nego i za televizijske emisije i videoigre) drži referencijski (dosegovno) jasnom i bez pribjegavanja službenoj, ali ne i razgovorno prihvaćenoj, „neutralnijoj“ varijanti „audiovizualno djelo“. 
Naime, kada je film u pitanju, pojava koju se uobličava (snimanjem ili računalno-animacijom izradom) i preobličava tijekom izrade (obradom, „postprodukcijom“) jest filmski zapis (filmska snimka), a to se tipično radi pomoću: a) uređivanja ili izbora prizora za snimanje (profilmskog prizora, objekta, seta); b) snimanjem uz pomoć filmskih naprava (tipično kamere i magnetofona, odnosno audiovizualnih digitalnih naprava); c) na filmsku vrpcu (ili memorijski disk), ili pak crtačkom, programskom računalnom izradom memorijskog zapisa; d) pomoću laboratorijske obrade filmske vrpce, odnosno elektroničke obrade analognog ili digitalnog zapisa slike i zvuka; e) montiranja slike i zvuka, ili, u elektroničkoj verziji, elektroničke, slikovno-zvukovne i montažne obrade, i najzad f) projekcije/ emitiranja za gledatelja. Sve se to čini uz provedbu funkcionalnih postupaka prilagođenih tehničkim uvjetima svake faze izrade i konačnom željenom izgledu filmske izrađevine u njezinu prikazivanju.

Proizvodnja filmskog djela, kao i drugih srodnih izrađevina, očito podrazumijeva složenu tehnologiju, sljednika nekog civilizacijskog tehnološkog razvojnog stanja (Li-Hua, 2009; Smith, 1970). Tvari koje se koriste u izradi filma (npr. filmska vrpca, elektromagnetska vrpca, memorijski disk i dr.), okoliš koji se priređuje i namjenjuje za izradu (ambijenti za snimanje, filmski studio, laboratorijski i montažerski odjeli i dr.), radne skupine uz podjelu rada (filmske ekipe, producenti, distributeri, prikazivač i dr.), kao i tehnička sredstva koja se upotrebljavaju (kamere, magnetofoni, rasvjetna tijela, laboratorijski strojevi, montažni stolovi, računala s računalnim programima i dr.) uglavnom su specijalizirani za izradu filma i rad s njime.

Dakako, u izradi filma može se koristiti minimalna tehnika i nespecijalizirana sredstva i postupci, ${ }^{3}$ ali prevladavaju specijalizirane tehničke naprave i postupci.

Proizvodnja tehničkih uvjeta za izradu filma (uređaja i njihovih dijelova, prostorija, tehnoloških procesa), uz kontinuirani tijek izuma i njihovih razrada, dijelom je različitih industrijskih i manufakturnih pogona i grana koje prate filmsku proizvodnju i prikazivanje. Primjerice, posebna je industrijska proizvodnja kamera i njezinih različitih dijelova za različite funkcionalne potrebe filmske proizvodnje; posebno je organizirana proizvodnja različitih nosača filmskog zapisa (filmskih vrpca i njihovih tipova, elektromagnetskih vrpca i diskova, laserskih zapisa i dr.); različitih projekcijskih ili emisijskih sredstava (poput projektora, specijaliziranih ekrana i eventualnih uređaja $s$ kojima su povezani: televizora, računala, tableta, mobitela); proizvodnja različitog procesnog instrumentarija (npr. montažnih strojeva, laboratorijskih strojeva, računalnih strojeva i programa; studijskih pomagala), različitih ploha i ambijenata za prikazivanje filma (npr. različitog tipa ekrana i njihovih refleksivnih i emitivnih svojstava, različite konstrukcije auditorija kina i razmještaja zvučnika u njima); konstrukcija različitih prostorija za rad (npr. studija, režijskih kabina, montažerskih prostorija, laboratorijskih prostorija, arhivskih prostorija, scenografskih radionica) itd. Svi ovi tehnološki aspekti javljaju se kao preduvjeti ili kao prateći uvjeti za izradu filmskog djela i standardno se osiguravaju.

Većina te industrijsko-proizvodne „podrške“ izrađivanju filma dislocirana je iz same „filmske industrije“ u odgovarajuće industrijske grane koje namjenski proizvode za izrađivanje filma.

Zaključimo: filmska izrađevina je ciljna posljedica, rezultat izrade, ona je - proizvod, dio tehnološkog procesa. ${ }^{4}$ Izrada filma je, u tom smislu, intencionalnim (namjeravanim, planiranim) i teleonomskim (svršnim, ciljnim, planski provedivim) procesom, a filmska izrađevina (proizvod, djelo) jest ciljnim

3 Primjerice, na emulziju filmske vrpce može se izravno crtati (bez uporabe kamere) i potom to projicirati (tzv. animacija bez kamere), pri čemu se rabi minimalna specijalizirana filmska tehnika (filmska vrpca i projektor) i bilo koje drugo, filmski nespecijalizirano, priručno sredstvo za crtanje po emulziji ili njezino grebanje.

4 Usp. Bordwell-Thompsonov zaključak o vezi filma i tehnologije: „Umjetnost filma ovisi o tehnologiji od najranijih eksperimenata s prividnim kretanjem do najnedavnijih računalnih programa. Ovisi također i o ljudima koji rabe tu tehnologiju, koji se udružuju da rade filmove, distribuiraju ih i pokazuju. Sve dok je film usmjeren publici, ma koliko maloj, on se uključuje u društvenu dinamiku proizvodnje, distribucije i prikazivanja.“ („The art of film depends on technology, from the earliest experiments in apparent motion to the most recent computer programs. It also depends on people who use that technology, who came together to make films, distribute them, and show them. As long as a film is aimed at an audience, however small, it enters a social dynamic of production, distribution, and exhibition“; Bordwell, Thompson, i Smith, 2017, str. 48) 
stanjem izrađivanja, kao što je slučaj i s većinom drugih izrađevina, odnosno proizvoda (Li-Hua, 2009, str. 20). Tom je izrađivanju namijenjena dodatna proizvodnja i razrada tehničkih naprava koje se rabe pri izradi i prikazivanju filma, pa je proizvodnja filma i sama svojevrsna tehnička grana (Bordwell, Thompson i Smith, prethodni citat /2017/; Salt, 2012), vezana uz brojne potporne industrijske grane. U tome se smislu često govori o „filmskoj industriji“ misleći na tehnološki temeljen filmski proces kao industrijski proces, ali i na sve ove popratne industrijske procese potaknute izradom filma i vezane uz nju.

\section{Film je doživljajno-uporabna izrađevina}

Kao i većina izrađevina, filmska izrađevina je teleonomska izrađevina, ima svoju namjenu, svoj krug posebnih i tipičnih uporaba za koje se izrađuje, ali i otvorene izglede za istraživanje netipičnih, odnosno nestandardiziranih mogućih uporaba i namjena. U izradu se i ide kako bi filmska izrađevina imala osobine što će je činiti pogodnom za predviđenu, odnosno moguću uporabu. Film je izrađevina s osobitom uporabnom namjenom.

No, koja je to uporaba?

Uza sve velike varijacije i višestrukosti svrha kojima filmska izrađevina može služiti, film se ipak, općenito uzevši, izrađuje za posve osobito tipizirano korištenje: film se, naime, izrađuje prvenstveno da bismo ga promatrali, odnosno, šire uzevši, da bismo na njega reagirali - da bi nas se dojmio na temelju njegove percepcije. On se obraća zamjećivaču, promatraču, opažaču - gledatelju-slušatelju kako bi potakao i vodio njegove reakcije. Te reakcije, kada ih uzimamo u njihovu ukupnom sklopu počevši od percepcije do složenog sudjelovanja ukupnih aktiviranih umnih sposobnosti i iskustava (čovjekovih spoznaja, interesa, emocija), objedinjeno nazivamo „filmski doživljaj“. Film se izrađuje prvenstveno radi njegova doživljavanja.

Po tome se film razlikuje od izrađevina kod kojih se jedino traži perceptivno prepoznavanje izrađevine i s njome vezane primjenjivačke svrhe (npr. prepoznavanje čekića, stolca, automobila, gradske ulice i sa stajališta onoga čemu služe u životu). Ovaj potonji tip izrađevina ne služi razrađivanju doživljaja njihova uporabitelja, ili barem se ne radi prvenstveno radi toga, nego da bi se obavio neki (utilitarni, praktični) posao, kako bi se time izravno („interventno“) djelovalo na životnu okolinu (usp. Turković, 2012, str. 57-58). Film je, pak, svojim izrađivanjem i strukturom usmjeren prvenstveno razradi svojega doživljavanja i njegova je "korist“ prvenstveno u razradi doživljajnih reakcija, njihovu služenju. ${ }^{5}$

Filmska registracija i reprodukcija je i izumljena kako bi priuštila raznovrsne specifične doživljaje, kako bi optičkom registracijom životnih promjena („pokreta“ u prizoru i pokreta točki promatranja) u razmjerno trajnom zapisu, omogućila njihovo gledateljsko raspoznavanje i upoznavanje (a s time i druge vezane doživljajne reakcije). I to u drugim, potonjim prigodama, različitim od onih u kojima su te promjene zabilježene, čime je omogućeno njihovo „vanjsko“, zapisno „pamćenje“ (Bazin, 1967, str. 7-8), tj. njihova raspoloživost ponavljanom doživljavanju u različitim geografskim i povijesno-

5 Doduše, kako su proizvodne svrhe razvojno otvorene, filmu se mogu dati i utilitarne svrhe. Postoji grana tzv. namjenskog filma kojoj je svrha upravo da utječe na životno djelovanje (izvan djelatnosti gledanja i doživljavanja filma). Primjerice, reklamni filmovi teže utjecati na životne izbore: na kupovanje određenog proizvoda koji se reklamira, na glasanje za određenog političara, na uplatu za neku dobrotvornu svrhu i dr. Dokumentarni promotivni filmovi o nekoj tvornici, izradi nekog proizvoda, nekoj zdravstvenoj ustanovi teže pojačati njihovu poznatost, ugled na odgovarajućem životnom području - teže povećati njihovu tržišnu, odnosno životno uporabnu efikasnost među stanovništvom. Aktivistički (i uopće propagandni) filmovi teže utjecati na cijeli spektar životnih ponašanja u danoj političkoj konstelaciji (npr. na bojkote određenih proizvoda i poduzeća, smjenu korumpiranih političara, organiziranje društvenih pokreta, podržavanje neke političke stranke). No ti filmovi ne utječu na ponašanje izravno (kako to primjerice čine naredbe), nego to čine posredno: teže nadasve utjecati na doživljajne temelje našeg snalaženja u životu (na naša znanja, uvjerenja, preferencije), pa da u nekoj prigodi, izvan neposrednih okolnosti gledanja i doživljavanja filma, eventualno „interventno“ djelujemo prema tim filmom potaknutim uvjerenjima. 
vremenskim prigodama, među različitim ljudima. A kako tehnički temeljena registracija omogućuje tehnički temeljeno „manipuliranje“ registracijom, filmaši su razrađivali i otkrivali što se sve doživljajno može oblikovati uporabom ovih ili onih mogućnosti koje je pružala zadana tehnologija. ${ }^{6}$ A kako su izrađivači filma u svojim oblikovnim nastojanjima bili suočeni s nizom prethodno neriješenih tehničkih problema u postizanju željenog filmskog dojma, davali su poticaj za njihovo inženjersko rješavanje, dakle za evolucijsko-adaptacijski razvoj tehnologije u službi doživljaja.?

S druge strane promotreno, sama recepcija, gledateljski doživljaj, rukovodi se nadasve strukturom samoga filmskog djela (izrađenog filmskog percepta, filmskog izlaganja). Ma koliko je filmski doživljaj pojedinog gledatelja individualan, njemu svojstven, on nije proizvoljan, neuvjetovan samom filmskom izrađevinom, pa ta uvjetovanost postaje zajedničkim temeljem za doživljaj filmskog djela bilo kojeg filmskog gledatelja, odnosno postaje zajednička filmskoj publici. Struktura filmskog djela potiče, vodi, odnosno artikulira reakciju gledatelja, uvjetuje je.

Jedan se tehnološki aspekt registracije pokazao osobito posljedičnim. Registracijski temeljena filmska izrađevina pokazala se pogodnom za mnogostruku (automatsku) replikaciju, umnažanje, multiplikaciju, tj. kopiranje, stvaranje brojnih kopija koje se mogu računati izvornom izrađevinom (Carroll, 2013), a to je omogućilo da se filmsko djelo može istovremeno prikazivati na mnogim mjestima i omogućilo široku distribuciju koja obuhvaća brojne gledatelje u zemlji proizvodnje, ali i po svijetu, što se pokazalo društveno i komunikacijski izrazito važno u formiranju masovne publike.

Zaključimo: ishodišna recepcija - doživljaj filmske izrađevine, njezina „doživljajna uporaba“ - jest, dakle, ciljem i regulatorom izrade filma. Gledateljeva recepcija filmske izrađevine je svojevrsna causa finalis - ciljni uzrok - izrade filma, varijacija u strukturama filma, kao i nastanka raznolikih tehnoloških sredstava i uvjeta za izradu.

6 Za razradu vrstovnog grananja do kojeg je došlo razvojnim ispitivanjem raznolikih doživljajnih mogućnosti koje su se otvarale proizvođačima filma usp. Turković, 2010. i Turković, 2021.

7 Primjerice, razrada različitih tipova emulzija na filmskoj vrpci javljala se kao odaziv na akutne snimateljske potrebe, kao nastojanje da se prekorače postojeća ograničenja, a time se otvarala mogućnost snimanja pod različitijim svjetlosnim uvjetima, boljem vladanju tonalnim, a poslije i kolorističkim odnosima u slici, a time i razradi odgovarajućih vizualnih vrijednosti filmske izrađevine. Razvoj različitih objektiva, mehanizama kamere, različitih tipova stativa proširivao je ne samo mogućnosti što će se sve moći snimiti, nego i kako će to biti snimljeno, tj. koje se sve doživljajne nijanse mogu postići uporabom različitih tipova objektiva, različitim pokretima kamere i dr. Ideja da se film ne mora sastojati samo od jedne snimke (jednog kadra) nekog zbivanja, nego da se može pratiti i više prizora, a i da se jedan prizor može pratiti povezanim nizom odvojenih snimaka, otvorilo je perspektivu montaži, a ova je podrazumijevala, a potom i potakla na izumljivanje i razvoj posebnog instrumentarija podređenog potrebama montažnog manipuliranja (npr. na izum različitih tipova montažnih stolova i njihovih mogućnosti, ljepilica i načina lijepljenja vrpce, a potom i različite tehničke i programske modalitete elektroničke montaže, različitih programa za digitalnu montažu), što je sve povećavalo ne samo različite mogućnosti montažnog rukovanja filmskim zapisom, nego i bolju i raznolikiju kontrolu nad montažnim, izlagačkim, oblikovanjem filmskog doživljaja. Samorazumljiva ideja da bi bilo dobro da prizori ne budu lišeni zvuka, nego da se uz vizualne promjene u prizoru registriraju i auditivne, potaklo je na izum različitih metoda sinkronog zapisivanja zvuka uz sliku (izum zvučnog filma) te različitih montažnih kombinacija između slikovnog i zvukovnog zapisa, a time otvorila mogućnosti istraživanja i ustanovljavanja što se sve može doživljajno postići raznovrsnim oblikovanjem samoga zvuka i veze zvuka i slike. Civilizacijsko uvođenje računala i različitih digitalnih programa omogućilo je njihovo „preuzimanje“, a potom i njihovu specijalističku razradu za potrebe izrade filma, pa su se otvorile nove izrađivačko-doživljajne mogućnosti digitalne proizvodnje, a potreba da se nadiđu polazna ograničenja digitalne proizvodnje tjerala su na dodatan tehnološki razvoj različitih programa i potrebnih računalnih uređaja. Itd. 


\section{Film je epistemološki modelotvorna izrađevina}

Takve izrađevine kojima je prvenstvena namjena da nadzirano i usmjeravano izazivaju (razrađuju, oblikuju) složen tip doživljaja odriješenog od životnih okolnosti u kojima se ta izrađevina percipira i nesvodivog na identifikaciju njegova tvarnosna nositelja (iako uvjetovano njime) drže se „modelotvornim“ (znakovnim, simbolskim, simulacijskim), onima, koje, filozofski rečeno, imaju epistemičko-modelotvornu funkciju. Pomoću takve izrađevine modeliraju se epistemički procesi čovjekova uma. (Turković, 2002, str. 82-84; Turković, 2012, str. 58-60; Turković, 2021, str. 23-25).

Doživljajno modeliranje se, htjelo-ne-htjelo, mora oslanjati na prisutne mogućnosti (sposobnosti, kapacitete) čovjekovih doživljajnih reakcija $i$ iskustvenih sadržaja, tj. na one njihove moduse $i$ tipove kakvi su tipično razvijeni u ukupnom životu pojedinca, filmskog gledatelja. Oslanja se na urođene perceptivno-spoznajne operacije, ali i na stečene perceptivno-spoznajne vještine, uhodane doživljajne strategije (rutine), kao i na opće znanje i iskustvo stečeno tijekom života, a naposljetku, stečeno i tijekom životne izloženosti filmskim djelima.

Ali, osobita je svrha filma da - oslanjajući se na ove sposobnosti i općeživotne doživljajne stečevine - njih ujedno $\mathrm{i}$ ispituje pod osobitim tvarnim okolnostima modelotvorstva, da ih nadzirano rekonstruira pod takvim okolnostima, odnosno da ih razrađuje i preobličava, ispituje mogućnosti koje se i ne javljaju tipično. Modelotvorne preoblike iskustvenih danosti i njihove razrade dovode često do neslućenih doživljajnih modaliteta (npr. u eksperimentalnim trendovima na svim područjima filmskog stvaralaštva, a osobito u eksperimentalnom filmu).

Film utoliko uspijeva biti epistemološkim sredstvom, svojevrsnom praktičnom epistemologijom (ili praktičkom psihologijom), tj. praktičkom (dnevno „eksperimentalnom“) disciplinom proučavanja i iskušavanja modusa i mogućnosti čovjekova duševnog odnosa prema svijetu i sebi samome. On je epistemološkim modelom, modelom kojim se prvenstveno vode i ispituju i razrađuju naše duhovne (duševne, ukupno doživljajne) reakcije na svijet, i pomoću kojeg se upućuje na njih (Turković, 2012, str. 62-72; Turković, 2021, str. 23-25).

Osobina je ovog upućivanja da će modeliranje posebno istaći pojedine aspekte ukupnih reakcija, učiniti ih prevladavajućim te ih time posebno nadzorno modelirati, uz potiskivanje drugih. Modeliranje je selektivno i ide u različitim smjerovima, cilja na različit tip doživljaja. Sve što se temelji na onim duševnim reakcijama čovjeka što su uvjetovane perceptivnom ponudom filmske izrađevine može postati izbornim i posebno izdvojenim (specijalističnim) predmetom (teleonomskim, planskim ciljem) modeliranja, modelotvornog variranja i artikulacije. Mogu to, npr, postati predodžbe o perceptivno dostupnom, „vanjskome svijetu“ i čovjekovu snalaženju u njemu (u igranom i dokumentarnom filmu npr.), mogu to postati - „unutarnji“ - pojmovno-predodžbeni sustavi pomoću kojih čovjek shvaća svijet i sebe u njemu (u znanstvenim, obrazovnim, tj. raspravljačkim filmovima), a predmetom modeliranja mogu postati $\mathrm{i}$, također „unutarnji“, dojmovno-predodžbeni duhovni sklopovi čovjeka i njegovih reakcija na svijet (tj. emocionalno-spoznajni, kakvi se modeliraju npr. u tzv. poetskim dokumentarcima, muzičkim spotovima, reklamnim filmovima, eksperimentalnim filmovima) (Turković, 2021).

Iz ovih je razloga, kod filma, kao i kod drugih umjetnosti, riječ o polimodelotvornosti: filmom se može modelirati više stvari odjednom (riječ je o složenoj modelotvornosti), odnosno može se modelirati svaki posebni doživljaj posebice (različitim specijaliziranim vrstama filmova i tipovima njihova strukturiranja; usp. Turković, 2010; Turković, 2021). U ovome potonjemu slučaju tek ukupnost isprobanih filmskih modela daje polimodelotvornu sliku ukupnog filmskog područja, 
tj. ukupnoga epistemološkog nastojanja filma u određenu vremenu te u ukupnome vremenskom rasponu njegova razvoja.

No, ovo grananje modelotvorno-epistemološke ponude prati i razgranatost i raznovrsnost pojedinačnih i skupnih gledateljskih interesa - onog što zbiljski gledatelj donosi gledanju, odnosno što je gledatelj spreman aktivirati od svojeg doživljajnog repertoara pristupajući filmu te prateći filmsko izlaganje. Gledatelji se individualno i skupno razlikuju u svojim doživljajnim sposobnostima, interesima i preferencijama, u različito su vrijeme različito raspoloženi za određene tipove doživljaja, donekle različito u različitim kulturnim (povijesnim i suvremenim) kontekstima, pa filmsko modeliranje to uglavnom prati (ali i, ponovimo, stvaralački potiče i modelira).

Zaključimo: po ovim modelotvorno-epistemološkim značajkama, filmska se izrađevina i njena (recepcijska) upotreba uklapaju u posebno područje čovjekovih duhovnih djelatnosti, onih u kojima čovjeku nije u prvome redu nakana da nekim sredstvom (filmom) izravno mijenja svoju neposrednu životnu okolinu (tj. da djeluje interventno na nju), već da njime utječe na samoga sebe, na duhovne temelje svoga opstanka u svijetu, svojega doživljavanja svijeta. Takvu se djelatnost ponekad, teorijski, naziva (u estetikama) kontemplativnom, refleksivnom, čisto promatračkom, bezinteresnom, idealnom, ili (u etološkim pristupima) radoznalom, istraživačkom, igralačkom. A filozofski i filozofsko-metodološki - epistemološkom, modelotvornom. Činjenica da je film epistemološkomodelotvornom izrađevinom ujedno je i ontološka odredba filma: film ontološki određuje činjenica da je bitno epistemološko-modelotvornom izrađevinom.

\section{Film je komunikacijska pojava}

Tretiranje filma kao izrađevine namijenjene prvenstveno poticanju i razradi gledateljevih doživljaja implicira da je po srijedi komunikacijski proces.

To je dvojako komunikacijski proces.

S jedne strane, filmski proces je komunikacijski prema teorijsko-informacijskom, transakcijskom modelu komunikacije: pošiljatelj/adresant izrađuje (enkodira) i šalje priopćenje (poruku; informacijski sadržaj) nekim fizičkim putem (provodnikom, kanalom) primatelju/adresatu koji je razumijeva (dekodira informacijski sadržaj). Primijenjeno na film, pošiljateljima bi bili filmski proizvođači; filmsko djelo funkcionira kao priopćenje, koje se, fizički pohranjeno (enkodirano) u nekom nosaču (filmskoj vrpci, elektromagnetskom, odnosno digitalnom zapisu), u krajnjoj instanci isporučuje (projekcijski ili emisijski dekodirano) gledateljima, koji su ciljani primatelji (doživljavatelji) filmskog priopćenja (Turković, 1979).

Kako je filmska komunikacija posredovana razmjerno trajnim, ili na dulje vrijeme raspoloživim fizičkim zapisom, pogodna je za vremensko-prostorni prijenos u različite situacije (Turković, 2012, str. 80-81). Filmsku se, dakle, komunikaciju po tome može držati tipično pripadnom dugoročnoj ili transsituacijskoj komunikaciji (neizravnoj, odložnoj komunikaciji) i po tome se razlikuje od kratkoročnih, situacijski ovisnih, jednokratnih komunikacija (kakve su one licem u lice ili interpersonalne komunikacije: npr. razgovor dvaju osoba nadohvat, telefonski ili videorazgovor i slično).

S druge strane, i neobično važno, transsituacijska komunikacija - posredovana „zapisanim“ priopćenjem (fiksiranim u razmjerno trajnom tvarnom obliku), tj. $u$ filmskom djelu - ne odvija se samo između „pošiljatelja“ i „primatelja“, nego i između samih „primatelja“. 
Naime, posredstvom filmske izrađevine stvara se osobita komunikacijska zajednica između sudionika u filmskome procesu: stvara se filmska publika (odnosno filmski gledatelji, filmsko gledateljstvo) ljudi koji „dijele“ filmske doživljaje. Iako, najčešće, članovi filmske publike ne moraju biti u izravnom međusobnom kontaktu dok gledaju film (iako to u tipičnim uvjetima kinogledanja na osobit način jesu), ${ }^{8}$ već time što je izložen filmovima kojima su podrazumijevano izloženi i drugi članovi publike, individualni se gledatelj uključuje u komunikacijsku zajednicu, publiku, koja međusobno, posredovano filmom, dijeli doživljajne poticaje određenog filma, odnosno filma uopće. Kako će se u narednom odjeljku upozoriti - to je komunikacijsko zajedništvo čimbenik zajedničke kulture gledatelja filma.

S ove "primateljske“ strane gledano, izrađivači i nuditelji filma nisu drugo do reprezentanti društvene ponude filmske izrađevine za unutar-gledateljsko komunikacijsko zajedništvo. Ciljana se komunikacija - u filmskom komunikacijskom, dugoročnom procesu koji je posredovan javno raspoloživim filmskim djelima - odigrava unutar samih članova filmske publike, unutar publike, $\mathrm{u}$ njihovoj participaciji u društveno raspoloživu događaju - gledanju filma. Proizvodnu i ponuđačku (distribucijsku i prikazivačku) stranu filmskog komunikacijskog procesa gledatelji neminovno podrazumijevaju, znajući da je film „netko“ izradio i da ga „netko“ stavlja na društveno raspolaganje, i to je „uračunato“ u doživljaj i same strukture filma (kao prethodno „društveno ovjerene“ stvari), ali dalje od tog općenito podrazumijevanja „adresanta“, gledatelj i ne mora ići. ${ }^{9}$

Komunikacijsko-epistemološko usuglašavanje nije usputna posljedica društvene raspoloživosti filma - ono je modelotvornim ciljem. Naime, filmsko se modeliranje i razvilo u posebnu djelatnost pod utjecajem činjenice da ono uspijeva posredovati komunikacijskom usklađivanju među ljudima što stupaju u epistemički dodir s filmom; filmom se upravo ispituju komunikacijski različito posljedični oblici epistemološkog modeliranja i ustaljuju oni koji se pokazuju društveno-koordinacijski djelotvornim. Disciplinarna raznovrsnost filma (Turković, 2010) može se, utoliko, držati njegovanjem različitih modelotvornih komunikacijskih mogućnosti.

S toga se motrišta onda svaki film, a i filmovi uzeti u svojoj ukupnosti, pokazuju komunikacijski polifunkcionalni: pojedinačni filmovi teže oživotvoravati više raznovrsnih komunikacijskih funkcija (npr. obavještavati o stanju stvari u svijetu, istodobno razrađivati kategorijski aparat pomoću kojeg interpretiramo svijet, mogu nam uz to razvijati vrijednosne /emocionalne/ stavove prema tim stanjima ili njihovim aspektima, ali i načelne interesne temelje koji ravnaju našim stavovima, pa time mogu nastojati sustavno utjecati i na neke oblike ponašanja što se temelje na tim interesima i stavovima, itd.). No, film može i specijalizirano i dominantno razvijati samo neku funkciju, pri čemu ukupno, genološko, polje filmova razrađuje funkcionalnu raznovrsnost moguću u danoj kulturi (Turković, 2021). Film se, kao ukupnost svih filmskih djela, utoliko pokazuje kao polifunkcionalno komunikacijsko polje.

8 Činjenica da su tradicijski gledatelji u međusobno „dodirnoj“ situaciji u kinodvorani, s obitelji pred kućnim televizijskim ekranom i sl., bila je tradicijski važna komponenta neposrednog komunikacijskog zajedništva gledatelja istog filma; grupno gledanje i ono individualno (ali uz podrazumijevanje da to individualno rade i drugi) dvije su životno isprepletene grane formiranja komunikacijskog zajedništva posredstvom filma.

9 Da je adresant, „pošiljatelj“ u komunikacijskom transakcijskom lancu, „mentalno rasplinuta“ stavka našeg doživljaja filma najširi je slučaj - nagađam da je najprošireniji kod tzv. „obične publike“. No, mogu se stvoriti okolnosti (npr. unutar modernističkog filma) i izlučiti segmenti publike koji uzimaju u obzir da je film i „vlasnička“ i „,autorska“ izrađevina, da postoje imenovane institucije (proizvodna poduzeća npr.) i imenovani pojedinci (npr. redatelji, scenaristi, glumci itd.) koji su izradili film i da je njihov „proizvodni“, odnosno „autorski trag“ u filmskom izlaganju važan aspekt globalnog doživljaja filma. Ovo dovodi do stanovite društvene diferencijacije filmske publike, primjerice na „običnu publiku“, koja se ne trudi prepoznavati proizvođače i autore filma i njihov „trag“ u filmu, i na „kultiviranu“, „medijski pismenu“ publiku, kojoj je „autorsko-ekspresijski“ aspekt filmskog djela doživljajno i interpretacijski važan. U potonjem slučaju „autor“ filma postaje personaliziranim sudionikom komunikacijskog procesa - onaj koji dijeli, posredstvom filma, svoje „doživljaje“ s gledateljem, kao što oni podrazumijevano dijele međusobno, pa time prestaje biti tek „anonimnim“ dijelom apersonalne društvene ponude filmske izrađevine. 
Iako je fikcionalno, imaginaciji usmjereno, odnosno imaginacijom vođeno filmovanje (igrani film), postalo vremenom središnjim pogoniteljem širenja i evolucije filma, upravo je polifunkcionalnost filma ovog učinilo masovno-komunikacijskom pojavom („masovnom umjetnošću“, „masovnim medijem“) - onom koja se na temeljima svoje tehnološke, razvijajuće, osnovice (multiplikacijske proizvodnje prilagođene širokoj distribuciji) obraćala raznolikim doživljajnim interesima „najšire publike”, ne isključujući pri tome posebne interese različitih ograničenijih društvenih grupa (Carroll, 2013), koje čine posebne publike.

Zaključimo: filmska izrađevina, dakle, a i cijeli filmski proces, podrazumijeva stanovito epistemološko usaglašavanje ljudi uvučenih u taj proces bilo kao izrađivača bilo kao publike i po tome je to ujedno i komunikacijski proces. Filmska izrađevina je upravo uobličivač komunikacijskog odnosa, ona je komunikat, odnosno priopćenje. Zahvaljujući svojoj epistemološkoj polifunkcionalnosti, film je postao masovno-komunikacijskom društvenom pojavom, konstitutivnim čimbenikom modernizma (Turković, 2008).

\section{Filmski proces je kulturni proces}

Reći za film da je komunikacijski proces zapravo podrazumijeva da je posrijedi općenitiji kulturni proces. Filmski komunikacijski proces tipično nije, ili nije takav obavezno, neposredno interpersonalni, situacijski, „licem u lice“, kao što je to razgovor među ljudima. Kako je posredovan trajnije raspoloživim filmskim zapisom on je tipično transsituacijski, tj. može se odvijati, i pretežito se odvija, u različitim pojedinačnim situacijama, nije (tipično ${ }^{10}$ ) vezan samo uz jednu, jedinstvenu, situaciju njegova doživljavanja, epistemološko-komunikacijskog dijeljenja. On je od prvog izuma pokazivao potencijale društvene, kulturne diseminacije, mogućnost da postane širok društvenokulturni fenomen.

Primjerice, kako je Edisonov suradnik (W. K. L. Dickson) na Edisonov poticaj izumio filmsko snimanje ubrzo su prve filmove počeli naširoko raspačavati SAD-om, sustavno prikazivati $u$ tzv. filmskim galerijama s nizom kinetoskopa (uređaja za prikazivanje filma) za individualno, samoposlužno gledanje filmova. Gotovo se odmah pokazao i međunarodni diseminacijski potencijal Edisonovog izuma: ideja Edisonova kinetografa (uređaja za snimanje filma) utjecala je na izum braće Lumière - kinematografa (uređaja za snimanje, razvijanje i projekciju filma), s kinoprojekcijom na ekran za veću skupinu ljudi. Kao i Edison, braća Lumière organizirali su svoje snimatelje-operatere da putujući prikazuju filmove, ne samo po Francuskoj, nego i uokolo po svijetu, što je opet utjecalo na dalje, o njima neovisne tehničke, snimateljske i prikazivačke pothvate posvuda.

No ova brza kulturna diseminacija filma (praćena progresivnim povećanjem broja onih koji proizvode, distribuiraju i prikazuju filmove, onih koji se upuštaju u dalje tehničke izume i unapređenja) ne bi bila moguća da modelotvorno-epistemološki efekti filmske snimke - doživljaji koje su pružale filmske snimke - nisu bile visoke atrakcijske vrijednosti (uz osobitu tehnološko-inovativnu atraktivnost izuma) čije je dalje razvijanje pridonijelo širenju kruga gledatelja i uspostavljanju osobitih - kulturno konstitutivnih - povratnih sprega.

10 Naglašeno je da je posrijedi „tipičan“ status filmske izrađevine i njezine komunikacijske „uporabe“, jer se i zapisni status filma i situacija prikazivanja može istraživati u eksperimentalnom (proširenom, multimedijskom, instalacijskom i sl.) okružju. Primjerice, projekcija filma može biti jedinstvena izvedba kako je to bio slučaj s Kariokinezom, Zlatka Hajdlera, 1965; autor izvedbe je prislanjao sirovu filmsku vrpcu na svjetiljku projektora, od topline se vrpca postupno topila i raspadala što se vidjelo na ekranu kao sliku raspadanja s različitim kolorističkim efektima. To je bila jednokratna, jedinstvena, situacijska izvedba, tek je naknadno rekonstruirana i zabilježena kao trajan filmski zapis. No, takve jedinstvene izvedbe nisu tipične varijante filma, ali jesu važne: i one itekako spadaju u modelotvorno-epistemološku domenu filma, u ispitivanje doživljajnih varijanti koje može pružiti filmska tehnologija ako se njome barata nestandardno. 
Jedna je povratna sprega osobito kulturno važna: društvena dugoročnost i proširenost općeg filmskog procesa omogućuje uspostavu povratne sprege između brojnih konteksta recepcije filma i ukupne proizvodnje i ponude filmskih izrađevina. Ta povratna sprega omogućuje svojevrsno "društveno testiranje", društvenu provjeru uspostavljenih epistemološko-komunikacijskih obrazaca u filmovima, ustaljenje uspješnih obrazaca, stjecanje vještina u njihovoj provedbi i primjeni. Posrijedi je stvaranje tradicija. Ono što se, tako, može ustaliti jesu transsituacijski uvjeti društveno djelotvornih epistemološko-komunikacijskih - pojedinačnih i pojedinčevih usuglašavanja.

Ovo ustaljivanje nadpojedinačnih, trassituacijskih društvenih uvjeta za pojedinačne doživljaje, očituje se u stabilizaciji filmskih postupaka i obrazaca, tj. tzv. «filmskog jezika», odnosno općeg komunikacijskog (semiotičkog) sustava (ili kodova), ustaljenog repertoara razlikovnih postupaka pomoću kojih se tipično ostvaruje svakovrsno društveno djelotvorno komunikacijsko usuglašavanje u svakoj prilici i bez obzira o kakvom je filmskom priopćenju riječ. Sastoji se potom u stabilizaciji (standardizaciji, konvencionalizaciji) tipova filmskog izlaganja, odnosno djelotvornih oblika funkcionalne organizacije filmske cjeline, i, najzad, u uvođenju i ustaljenju filmskih vrsta, odnosno općih funkcionalno-strukturalnih obrazaca (struktura) s izborom kojih se ostvaruju posebni tipski komunikacijsko-epistemološki učinci.

Ti se uvjeti javljaju kao društvene norme (standardi, vrednote, običaji) što transsituacijski reguliraju proizvodnju i recepciju filma, svaki individualni pothvat. Drugačije rečeno, svaki pojedinačan filmski čin (proizvodni, recepcijski) pokazuje se kao čin provedbenog utvrđivanja koje su to društvene norme (koji standardi, koje vrednote) što djelotvorno (modelotvorno) artikuliraju doživljajne reakcije.

Ovi društveni uvjeti utjelovljeni su u filmskim izrađevinama u obliku obrazaca (uzoraka) što su iskustveno razaberivi i usvojivi kada im se bude dostatno i prikladno izložen. Oni su predmetom osobnog učenja, odnosno društvenog odgoja i obrazovanja. Ti su obrasci, utoliko, i prenosivi; u pitanju je prenosivo iskustvo, s osobe na osobu, s generacije na generaciju, s društvene zajednice na društvenu zajednicu.

Sve ovo zajedno čini filmsku izrađevinu kulturalnim artefaktom, sav filmski i komunikacijski proces čini kulturnim procesom, osposobljavanje za filmsku djelatnost (proizvodnu i recepcijsku) čini procesom kultivacije, raspačavanje filma čini procesom kulturne difuzije, a transkulturni prijenos (povijesno-geografski) povlači i procese asimilacije (prilagođavanje praksa preuzetih od drugih, tuđih obrazaca vlastitoj kulturnoj sredini).

Kao što se epistemološko iskustvo temelji na raspoloživim doživljajnim sposobnostima pojedinaca i ljudi uopće, tako se i kulturalni procesi temelje na opće raspoloživim kulturalnim (normativnim, obraščanim i odgojno-obrazovnim) procesima u društvu. U tom smislu kulturalna socijalizacija komunikacijske modelotvornosti filma oslanja se na „mehanizme“ kulture što su već uhodani i raspoloživi u danome društvu. Npr. filmska se običajnost oslanja na običajnosti razrađene u drugim srodnim komunikacijskim sustavima i vezuje uz njih (npr. uz druge umjetnosti - književnost, kazalište, fotografiju, likovne umjetnosti, glazbu, arhitekturu; uz druge zabavne industrije - sportske igre, sajmove, zabavne parkove; uz druge medije masovne komunikacije - novine, radio, televizija, internet i dr.), kao i na opće kulturotvorno sudjelovanje drugih kulturalnih sustava u izgradnji filmske običajnosti (npr. usmene komunikacije o filmu, sudjelovanje novinskih tekstova, kritika i teorije u iskazivanju i konstituiranju postulativnih normi i uvjerenja što ravnaju filmskim procesom, potom obrazovnih mehanizama i slično). Film je, po tome, nasljedovateljem opće kulture. 
Modelotvornost filma, međutim, omogućuje da regulativnost ne ide samo od raspoložive društvenosti filmu, već i povratno: od filmske izrađevine društvu. Naime, film nije samo reguliran već je i sam društveno regulativan, on pruža osobite epistemološko-komunikacijske modelotvorne paradigme za različite kulturne konstitucije. Film utječe na druge umjetnosti, utječe na modele i djelotvornost obrazovanja, na svakodnevne kulturne modele (npr. ponašanja, odijevanja, procjena životnih prilika). Iskustvo stjecano filmom može utjecati na mnoge aspekte našega života. Utoliko ukupni filmski fenomen posjeduje stanovit stupanj kulturne autonomije u kontekstu ukupne kulture, film uspostavlja dostatan stupanj kulturalne samoregulativnosti pa utoliko tvori osobito područje kulture na koje se misli kada se govori o filmskoj, odnosno audiovizualnoj kulturi.

Kako je i taj kulturalni, polifunkcionalni, filmski sustav običajno reguliran (te se pojedine vrste i njima pripadne norme običajno usuglašuju dobivajući različitu relacijsku vrijednost u danome sustavu), to upravo oblik funkcionalno-strukturalne diferencijacije unutar dane kulture i običajne regulacije te diferencijacije uvjetuje individualitet dane kulture (tzv. kulturalni stil, ili, također: povijesni stil, stilsko razdoblje), uvjetuje koordiniranu raznolikost kulturalnih područja (filmskih supkultura; npr. tzv. „dominantnu igranofilmsku kulturu“; znanstveno-obrazovnu kulturu, alternativne supkulturne varijetete i dr.). Opet, promjene u svim tim vrstama i njihovim uzajamnim odnosima činiteljima su općih kulturalnih promjena (tj. promjena individualnih filmskih kultura, odnosno globalnih kultura, općih, periodskih, stilova; npr. klasičnog stila, modernističkog i dr.).

Zaključimo: polifunkcionalnost filma kombinirana s njegovom zapisnom i komunikacijskom transsituacionošću učinila je film pogodnim za širok običajni obuhvat pojedinaca u društvu u kojem je film raspoloživ te je tako filmski sustav postao sutvorcem kulture, sa sličnim sustavima masovnih komunikacija, onima publicistike, radija i televizije, pa i osobitih diferencijacija unutar kultura, primjerice na razvoj tzv. masovne kulture, ali i mnoge kulturne rukavce, različite nemasovne varijante kulture, različite difuzijski „rezervatske“ oblike (npr. tzv. umjetnički film, eksperimentalni film, znanstveni film, nastavni film, pornografski film i dr.).

\section{Film je katalizator društvenog organiziranja i organizacija}

Svim svojim prethodnim istaknutim osobinama film je katalizator društvenog - industrijskogospodarskog i kulturno-institucijskog organiziranja.

(a) Kao tehnološki temeljen proces, kako smo već naznačili u odjeljku o izrađivačkoj prirodi filma, filmski proces podrazumijevao je razradu i proizvodnju raznolikog instrumentarija za svoje potrebe (npr. kamera i njezine opreme, vrpci, a poslije i raznih elektroničkih nosača, rasvjetnih tijela, montažne opreme, projektora, zapisivača i reproduktora zvuka i mnogo što drugo), razvitak tehnoloških procesa (npr. procesa samog snimanja filma, razvijanja filma, montaže, projekcije, transporta i dr.) ambijenata za sve to (studija za snimanje, laboratorija, scenografskih radionica, spremišta, kinodvorana i dr.), a sve je to podrazumijevalo organiziranje specijalističkih industrijsko-gospodarskih pogona: laboratorija, tvornica, različitog tipa poduzeća ili specijaliziranih proizvodnji unutar poduzeća. Primjerice, već se samo tehnološko izumijevanje i polazno plasiranje filma u javnost odvijalo u laboratorijima poduzetnika, onom Edisona u SAD-u, odnosno braće Lumière u Francuskoj, a njihova su poduzeća ta koja su bila prvim nositeljima proizvodnje tehnike za snimanje i distribuciju. Popularnost filma i globalni tržišni izgledi koju je ona otvorila generirala je cijelo industrijsko-gospodarsko područje u službi filma, osobitu filmsku, odnosno audiovizualnu industriju. 
(b) Kao epistemološko-komunikacijski proces film je bio inherentno društven fenomen, podrazumijevao je društvenu samoorganizaciju, a potom i vođenu organizaciju njegove proizvodnje i njegove recepcije.

Iako filmski proces može biti razmjerno individualiziran, npr. mogao je podrazumijevati samo jednog čovjeka za proizvodnju i prezentaciju filma, ${ }^{11}$ minimalnu stvaralačku razradu, on je tipično kolektivan, i po načinu proizvodnje, sustavu distribucije i prikazivanja, te masovan po publici.

Razradom strukturiranja filmskog izlaganja, koje je postajalo sve složenije, epistemološkokomunikacijski zahtjevnije uz uporabu sve brojnijeg i raznovrsnijeg specijaliziranog instrumentarija i tehnoloških procesa, proizvodnja filma postala je kolektivnim pothvatom, formirala se podjela rada na razmjerne specijalnosti, operativne uloge i hijerarhijske odnose. Primjerice za snimanje filma formirala se ekipa, grupa ljudi koji surađuju na samoj izradi filma, a ova je bila sastavljena od niza strukovnih podekipa (proizvodnih odjela, sektora; npr. režijskog sektora, snimateljskog, scenografskog, montažerskog i dr., s vlastitom hijerarhijom nadležnosti), među njima dio stvaralačke orijentacije s „autorskim“ nadležnostima (npr. scenarist, redatelj, snimatelj, scenograf, kompozitor glazbe, montažer i dr.), a dio „tehničke“ orijentacije, kao tehnička podrška onim prvima (npr. razni asistenti, mikromani, farmajstori, klaperi, električari, stolari, rekviziteri), a sve to uz raznoliko uzajamno usuglašavanje njihova rada. Mnoge od tih struka vremenom su organizirale svoja društva i sindikate koji su se brinuli i o njihovu društvenom stvaralačkom dignitetu, ali i o standardima proizvodnje i njihova ishoda.

I, kako je to već spominjano, sve brojnija, a potom i masovna publika, počela se diferencirati u specifične doživljajne skupine koje su postale regulatorom određena tipa stvaralaštva. Primjerice, uspostavila se orijentacija tzv. širokoj (ili masovnoj) publici (koja je dobno, rodno, statusno, obrazovanjem različita), a kojoj su se namjenjivali tzv. filmovi „za zabavu“ (tj. „zabavi“ orijentirano stvaralaštvo; Turković, 2005), formirale su se interesno različite podskupine publike (npr. muška, ženska, dječja publika, publika etičkih manjina, različiti tipovi visokoobrazovane, „elitne“ publike i dr.) na koje su posebno ciljali filmovi određene vrste i stila (npr. akcijski filmovi ciljali su mušku publiku, melodrame pretežito žensku, dječji filmovi dječju, „umjetnički filmovi“ obrazovanu publiku, eksperimentalni također itd.). Neke su se skupine institucijski organizirale (npr. u „društva prijatelja filma“, filmske klubove, grupe fanova i dr.), ili su ih „organizirala“ u koherentnu situacijsku publiku različito specijalizirana kina i manifestacije (npr. repertoarna kina za široku publiku, dvorane kinoteke i „umjetnička kina“ za filmske ljubitelje i poznavatelje, pornokina za takve interese, festivali za prestižne umjetničke filmove i njihove pratitelje, ali i festivali za pratitelje pojedinih vrsta filmova /npr. festival eksperimentalnog, animiranog, dokumentarnog, animiranog, znanstveno fantastičnog i dr. filma/).

(c) Kao kulturni proces, filmski proces je podrazumijevao popratni proces formiranja različitih profesija i institucija kojima je osnovna djelatnost razvoj i širenje filmske kulture.

Primjerice, obrazovanje za rad na filmu izašlo je iz isključivo „šegrtskog“ tipa (učenje kroz aktivni rad na filmu s iskusnijim profesionalcima) u posebne institucije: filmske akademije, škole s filmsko-obrazovnim programom, radionice, tečajeve i dr., a sve to uz njegovanje različitih obrazovnih svrha i različitih

11 Primjerice u slučaju uporaba lumièreovskih kamera, kojima se snimalo, razvijalo film i projiciralo ga, sve je to obavljao jedan operater, koji je birao što će snimati, eventualno pripremio prizor za snimanje, to snimio na mali kolut filma, razvio vrpcu i projicirao publici (Lumière, 1933. str. 50). Mogućnost takvog individualiziranog procesa zadržala se u povijesti filma, oživljena pojavom amaterskog filmovanja, potom među eksperimentalistima, a u suvremeno vrijeme pojavom video snimanja, montaže i prezentacije (kamerom, fotografskim aparatom, pametnim mobitelom), bilo amaterske ili umjetničke (npr. videoumjetnost, personalni dokumentarac). 
formalnih standardizacija (obrazovnih programa, specijalizacija), sve praćeno obrazovnom literaturom (filmskim priručnicima, udžbenicima, rječnicima, enciklopedijama) i standardizacijom nazivlja.

Odrana su se izlučili specijalizirani filmski novinari, kritičari, teoretičari koji su bili čimbenici svojevrsne javne „kulturne politike“, spoznajno-vrijednosne regulacije onoga što se sve smatra kulturno vrijednim u filmu. Vremenom su se integrirali u različite institucijske niše: kulturne rubrike novina, specijalizirane filmske časopise, filmske institute, te u školski i obrazovni institucijski sustav. Formirani su posebni (humanistički) studiji filma, posebni sveučilišni smjerovi (npr. filmološki, medijski studiji), razvila se specijalizirana naklada: kulturne (filmske) rubrike u novinama, specijalizirani filmski časopisi, izdanja knjiga o filmu, te mnoge druge publicističke vrste. Kao i proizvođači, i profesionalni pratitelji filma organiziraju se u različitim udruženjima (npr. društvo filmskih kritičara, društvo filmskih teoretičara) i filmskim institutima.

Postupno formirana spoznaja o kulturnoj važnosti filma dovela je do uvođenja raznovrsnih institucija kojima je cilj poticanje filmskog stvaralaštva i kulture (filmske, odnosno medijske „pismenosti“), pored ili kao korekcija samoodrživom „komercijalnom“ području. Primjerice, tome služe različiti filmski fondovi (poput HAVC-a) koji potiču proizvodnju filmova i prateće kulturne djelatnosti. Formirale su se institucije za arhiviranje, restauraciju i kultivacijsko prikazivanje arhivskih filmova (kinoteke, instituti, nakladnici videoizdanja), a tu, naravno, spada i prije naznačeno akademsko izučavanje filma na sveučilištima i u općeobrazovnim školama.

Zaključimo: kao i većina društveno relevantnih područja, film, odnosno filmsko područje institucionalno je podržano i integrirano u druga institucionalna područja društva. 


\section{Ukupni zaključak}

Filmsko, audiovizualno, djelo višestruka je i po implikacijama složena pojava. Ono je lokalna, fizička, materijalna pojava u ljudskom okružju, s kojom se može rukovati, nju se može materijalno preinačavati, prema njoj se mogu formirati raznoliki operativni odnosi. Nije „prirodna“ pojava, ona koju su samorodno formirale prirodne sile, nego je izrađevina, rezultat složenog, tehnološki temeljenog ljudskog proizvodnog (stvaralačkog) rada. Kao većina tehnološki temeljenih izrađevina, film je rađen s određenom svrhom, no za razliku od drugih utilitarnih izrađevina, onih koje služe djelatnim potrebama dnevnog života ljudi, film je nadasve usmjeren na poticanje i razradu čovjekovih doživljajnih reakcija, na njihovo modeliranje, a to modeliranje je omogućeno upravo materijalnom i tehnološkom operativnom utemeljenošću filma: između tehnologije i modelotvornih mogućnosti filmske izrađevine postoji postojana, ali i povijesno dinamična, razvojno otvorena povratna sprega. Epistemološki cilj filmske izrađevine inherentno je bio društveno-komunikacijski: modelirali su se zapisni uvjeti („zadani“ u postojanom nositelju) za doživljaj potencijalnih i aktualnih filmskih gledatelja, čime se stvarala situacija za uzajamno (komunikacijsko) dijeljenje tih doživljaja: između tvoraca filma i gledatelja i između samih gledatelja koji gledaju film. Time što gledaju filmove pod istim zapisnim uvjetima, gledatelji čine svojevrsnu komunikacijsku zajednicu - publiku. Modelotvorna otvorenost i izdiferenciranost (modeliraju se i modelski ispituju različite doživljajne mogućnosti čovjeka) također je bila vođena povratnom spregom između odaziva ovog ili onog profila publike, ovog ili onog doživljajnog interesa gledatelja i tvorbenih (stvaralačkih) modelotvornih mogućnosti. Posljedica ovog posljednjeg bila je u izdiferenciranju različitih vrsta filmova (filmskih rodova, žanrova, stilova) te stvaranje za svaku vrstu posebnih konstelacija filmske publike, ali i zadovoljavanje različitih doživljajnih interesa pojedinaca. Cijeli je taj proces bio izrazito kulturni: podrazumijevao je složenu kulturnu difuziju i asimilaciju, uz prateće kulturne diferencijacije i složene interpretacijske pristupe tzv. sekundarne komunikacije, one u kojoj se komunicira o filmu i njome dodatno reguliraju kulturalni procesi (npr. kritikom, teorijom, obrazovanjem, potporama). Cijeli se taj epistemološkokomunikacijski proces odvijao uz razvoj institucionalizacije, institucijske podrške, standardizacije, ali i odstupanja od standardizacije s otvaranjem novih modelotvornih mogućnosti, na koje je navodila temeljna epistemološko-modelotvorna otvorenost stvaralaštva.

Svi su navedeni aspekti ukupnog filmskog procesa na ovaj ili onaj način međupovezani, ispremreženi. Mogu se shvatiti kao jedinstven industrijski, gospodarski, kulturni i povijesni kompleks, kojeg se jedinstveno imenuje - kinematografija, audiovizualno područje. Međutim, daleko od toga da je posrijedi homogeno područje; posrijedi je policentrično područje, s često konfliktnim trendovima, ali i nadalje povezano raznolikim tipovima veza koje indiciraju njegovo generičko jedinstvo.

Svojom mnogostrukošću film je predmetom proučavanja različitih znanstvenih disciplina: filmologije, povijesti, kulturologije, psihologije, sociologije, komunikologije i medijskih znanosti, različitih tehničkih znanosti, ekonomije i dr., ali i interdisciplinarnih, integrativnih pristupa. 


\section{Literatura}

Bazin, A. 1967. (1958). Šta je film? I. (prev. I. Pavlović). Institut za film.

Bordwell, D., Thompson, K. i Smith, J. (2017). Film Art: an Introduction. McGraw-Hill.

Carroll, N. (2008). The Philosophy of Motion Pictures. Blackwell.

Carroll, N. (2013). The Ontology of Mass Art. U: Carroll, N. 2013. Minerva's Night Out. Philosophy, Pop Culture, and Moving Pictures. Blackwell, 9-28.

Filding R. (ur.). (1983 / 1967). A Technological History Of Motion Pictures and Television; An Anthology From the Pages of the Journal of The Society of Motion Picture and Television Engineers. University of California Press.

Hochberg, J. i Brooks, V. (1962). Pictorial Recognition as an Unlearned Ability?. American Journal of Psychology 75(4), 624-628.

Li-Hua, R. (2009). Definitions of Technology. U: Olsen, J. K. B., Pedersen, S. A. i Hendricks, V. F. (ur.) A Companion to the Philosophy of Technology. Wiley-Blackwell, 18-22.

Lumière, Luis. (1933). The Lumière Cinematograph. U: Filding R. (ur.). (1983 /1967), 49-51.

Manovich, L. (2001). The Language of New Media. MIT Press.

Salt, B. (2009; treće dopunjeno izdanje). Film Style and Technology. History and Analysis. Starword.

Smith, C. S. (1970). Art, Technology, and Science: Notes on Their Historical Interaction. Technology and Culture, Vol. 11, No. 4. 11(4), 493-549.

Turković, H. (1979). Komunikacijski model filmskog procesa. Filmske sveske br. 3. Institut za film, 153-169.

Turković, H. (2002). Razumijevanje perspektive. Teorija likovnog razabiranja. Durieux.

Turković, H. (2005). Što je zabava. U: Turković, H. (2005). Film: zabava, žanr, stil. Hrvatski filmski savez, 13-48.

Turković, H. (2008). Metakomunikacijska regulacija komunikacije. U: H. Turković. Retoričke regulacije. Stilizacije, stilske figure i regulacija filmskog i književnog izlaganja. AGM, 193-214.

Turković, H. (2009). Filmski modernizam u ideološkom i populističkom okruženju, Hrvatski filmski ljetopis. 59/2009. Hrvatski filmski savez, 92-106.

Turković, H. (2010). Nacrt filmske genologije. Matica hrvatska.

Turković, H. (2012). Teorija filma. Prizor, montaža, tematizacija. Meandarmedia.

Turković, H. (2021). Tipovi filmskog izlaganja. Hrvatski filmski savez; Društvo hrvatskih filmskih redatelja. 


\title{
All a film is
}

\section{HRVOJE TURKOVIĆ, PhD}

Academy of Dramatic Art, University of Zagreb

\begin{abstract}
In the paper the crucial speculative, epistemological and ontological, determinants of film work and cinema are presented, those that could orient empirical research. (1) Film work is a delimited material object in the human environment, it can be manipulated, and people can form different life relationships to it. (2) Film work is an artifact technologically produced, entailing differential development of the productionally needed technique. (3) Film work is produced in order to stimulate a mental, experiential reaction, it is the main purpose of the artifact. (4) Technological control over the details of production process enables controlled modeling of possible experiences afforded by the film artifact; a film is epistemological modeling artifact. The film process is also a communicational process; epistemological modeling implies the two types of communicational sharing: the makers of the artifact are addressing by film work potential or actual spectators, and, further, spectators share experiences offered by film work among themselves. (5) All previously mentioned characteristics of film work and film process are social-cultural act as well. The film relies on the surrounding cultural resources, and is a cultural recourse in its own right. (6) Being a technological, communicational and cultural phenomenon, by implication social, film work and film process are also socially organized, institutionally sustained.
\end{abstract}

Keywords: film-work, film technology, film epistemology, film ontology, film culture 